\title{
Research Note \\ Tourism Ecocertification in the International Year of Ecotourism
}

\author{
Ralf Buckley \\ Director International Centre for Ecotourism Research, Griffith University, \\ Parklands Drive, Southport, QId 4215, Australia
}

Ecocertification and accreditation were hot topics for corridor discussion at the World Ecotourism Summit (WES) in Quebec in May 2002. The issue appears to have become quite politicised. Here, therefore, is an attem pt to summarise recent events and, to some degree at least, to deconstruct their political context. There's a degree of secrecy, with some critical technical and financial information not yet available to the public. The comments below are based on public information. In some cases I have also identified where further information should be available and may possibly become public in due course.

\section{Terminology}

Historically, there has been confusion over the way in which different terms have been used. Current international usage, and the way the terms are employed below, is as follows. Certification is a formal process under which a nominally independent body certifies to other interested parties, such as tourists, marketing agencies and regulators, that a tourism provider complies with a specified standard. For ecocertification this is of course an environmental standard. Certification programmes may be operated either by private or public agencies. Both retail customers and regulators are more likely to pay heed to certification schemes that are recognised in government legislation, are independently audited, use performance-based rather than process-based standards, and publish both the standards and the evaluation process openly.

Accreditation is a higher-tier process by which a body independent of any of the certification agencies certifies that the certification schemes themselves meet an appropriate standard. An accreditation agency accredits the certification agencies to certify individual tourism operators, products or people. Accreditation is particularly significant when there are large numbers of competing certification schemes operating to widely different standards, so that it is difficult for a consumer to judge just what each one means and how reliable it may be.

Note that the distinction between certification and accreditation is jargon; that is, the terms are given a specialist meaning by a particular group of people, different or more precise than their normal meanings in common language, for example, as given in a dictionary. Note also that under this terminology, schemes such as Australia's Nature and Ecotourism Accreditation Program (NEAP) would be considered as ecocertification rather than accreditation.

The term ecolabel has two meanings, one much more specific than the other. In its broad sense an ecolabel is simply any kind of label with environmental connotations. If a tour operator describes one of its products as an ecotour, for 
example, irrespective of any ecocertification, that is an ecolabel in the broad sense. The term ecolabel also has a much more specific meaning, however, in international trade law. Current interpretations of multilateral trading agreements allow nations, subject to a number of other caveats, to restrict the import of products whose use would cause differentially higher environmental impacts in the importing nation, but not those whose production processes cause differentially high impacts in the exporting nation. Products may, however, be labelled with environmental information on production processes, to allow individual consumers to select lower-impact products, such as dolphin-friendly tuna or sustainably harvested timber. An importing nation cannot insist on ecolabels or restrict unlabelled products, but even the right of private companies to use ecolabels at all has been subject to international trade disputes. Ecocertification in tourism is a form of ecolabel in the international trade sense.

\section{Current Ecocertification Schemes in Tourism}

There are numerous ecocertification and environmental award schemes currently operating in the tourism sector, in various countries and languages. These range from the highly localised and specialised to the very general and globalised. Font et al. (2001) identified 73 schemes and summarised current features of 48. Honey and Rome (2001) analysed nine well-known programmes. A recent review by the World Tourism Organisation(Yunis, 2002)identified over 100 schemes with around 7000 member companies overall. Some of these lists may also include environmental award programmes and corporate codes of conduct as well as certification schemes. Many states, countries and regions have their own schemes in operation. Examples include a number of European nations (Hamele, 2001), Australia (EAA, 2002), Costa Rica (CST, 2002) and more. There are also independent schemes run by large outbound tour packagers such as TUI (2002) in Germany, which are not marketed as ecocertification programmes but which may in practice be at least as influential, since they directly affect the flow of bookings to individual tour operators. TUI compiles environmental data on both destinations and enterprises. Its evaluation form for destinations, for example, contains about 250 individual parameters (TUI, 2002), some qualitative and some quantitative.

There is as yet no functioning accreditation body for tourism ecocertification schemes. A proposal to establish an accreditation body was floated in late 2001 (see below) and is still under debate. Tourism ecocertification schemes are likely to be subject to trade practices legislation in many jurisdictions (Buckley, 2001a), but I am not aware of any actions brought under such legislation to date. Nor do there seem to have been any trade disputes relating to ecolabels in tourism. Such disputes are less likely in tourism than in other sectors, for reasons outlined by Buckley (2001a).

There is a certain degree of turnover in certification schemes of any type, depending on the use and acceptance of the labels and the financial and political survival of the certifying organisations (Buckley, 2001b). Tourism Council Australia, for example, one of Australia's national tourism industry associations, used to operate a business quality certification programme. TCA certification had been adopted by some of Australia's protected area management agencies as 
one criterion for granting preferential permitting conditions. In 2001, however, TCA suffered financial collapse and ceased to exist, along with its certification programme. The status of the associated permits was hence cast into doubt.

\section{The Mohonk Agreement}

In November 2000 the Institute of Policy Studies (IPS) in Washington DC, USA, convened a meeting at a venue known as Mohonk House to discuss ecocertification in tourism. The meeting included representatives from various existing tourism ecocertification schemes, and from successful ecocertification programmes in other industry sectors. A number of tour operators, ecotourism associations and researchers, and other interested parties were also involved. Some concerns were expressed at the World Ecotourism Summit that the Mohonk meeting may not have been open to all, or representative of all stakeholder groups. This, however, probably reflects limitations on space and funding rather than any deliberate intent.

Organisations represented at the Mohonk meeting included existing ecocertification schemes from Australia, the Asia-Pacific, the Caribbean, Germany and Guatemala; ecotourism associations such as The International Ecotourism Society (TIES) and Business Enterprises for Sustainable Tourism (BEST); conservation groups such as Conservation International (CI), the World Wide Fund for Nature (WWF), and the Rainforest Alliance (RA); and multilateral organisations such as the United Nations Environment Programme (UNEP).

The meeting produced three main outcomes: a report (Honey \& Rome, 2001); the Mohonk Agreement, a set of guiding principles for tourism ecocertification schemes; and a proposal for an accreditation body, the Sustainable Tourism Stewardship Council. A further book is in progress (Honey, 2002).

\section{The FSC Model}

The STSC proposal was modelled on the existing and successful Forest Stewardship Council, an accreditation programme run by the Rainforest Alliance for sustainable-timber certification schemes. In the retail timber, building-products and furniture sectors, it is FSC-accredited products which have been adopted by manufacturers, retailers and consumers, in preference to products certified solely by an industry-based scheme.

The FSC was established in 1993, and works by balancing interest of three major stakeholder 'chambers': environment, economic and social. As of 2000, FSC was operating in 40 countries and over 650 retail firms in Europe and the US were buying FSC certified timber (Honey \& Rome, 2001). One significant reason for this success, however, 'is the threat that environmental groups will organise consumer boycotts against retailers who don't buy FSC products' (Honey \& Rome, 2001: 56). The threat of major economic loss is a much more powerful incentive than the offer of a relatively small economic gain, available in the early stages of certification programmes. Could this happen in tourism? Large retail tourism organisations control very considerable purchasing power, even if they do not own the various companies whose products they sell. Imagine, for example, if an environmental advocacy group organised a consumer boycott of major airline holiday programmes unless those programmes insisted that all the prod- 
ucts they sell must achieve environmental certification accredited under STSC. Would that be any different from the history of the FSC?

\section{Draft International Ecotourism Standard}

The World Ecotourism Summit was used as a venue by Green Globe 21 (GG21) and the Ecotourism Association of Australia (EAA) to launch a draft International Ecotourism Standard for Certification (IESC). Essentially, this is the Australian NEAP (EAA, 2002), offered in other countries through Green Globe 21. Copies of the draft were available from the EAA stand at the WES trade show and are also available on both websites (EAA, 2002; GGAP, 2002). The initiative was also announced by the President of EAA as part of the WES program, and was launched at a side meeting hosted by the Australian High Commissioner. A final version is expected to be launched at the EAA's conference in Cairns in October 2002. As noted in the accompanying report on the World Ecotourism Summit, this EAA event has been endorsed as one of several end-of-year events for the International Year of Ecotourism.

While NEAP is an entirely Australian program, GG21 has three nodes (GG21, 2002): Green Globe 21 headquarters in the UK, GGAP in the Asia-Pacific, and CAST, Caribbean Action for Sustainable Tourism, in the Americas. As of 12 June 2002, however, the GG21 and GGAP weblinks to CAST lead to a web page advising that the site name has been bought by another commercial client. GGAP is an Australian company owned jointly by GG21 and Australia's Cooperative Research Centre for Sustainable Tourism (CRCST). CRCST has made heavy cash investments in GGAP. In addition, the compilation of technical data which GG21 relies on to establish its benchmarking program, was carried out largely as research projects funded through CRCST. Given that over $90 \%$ of CRCST funds have been provided by the Australian taxpayer (CRCST, 2002), largely as a result of grant applications written by university researchers, it was somewhat amusing to hear belittling references at the IESC launch to 'academics who sit around writing grant applications'!

NEAP and GG21 have very different structures, and as anticipated (Buckley, 2001b), the proposed draft international standard appears as a rather awkward amalgam of the two. Essentially, NEAP uses a fixed standard based on relatively detailed performance checklists, and is applied to individual tourism products rather than operating firms. The level of certification depends on how many criteria are met. In theory, if every nature tourism product in Australia met enough of the criteria, they could all receive certification at the highest level. Certification under GG21, in contrast, is supposed to depend on an operator's performance relative to the rest of its own industry subsector in its own country. Of course, to be reliable this would require quantative data on the actual performance of all operators in each subsector and country, for each parameter used in GG21 certification. In practice, such data are rather scarce. CRCST has attempted to compile such data on behalf of GGAP. It has not released the results, but GGAP has indicated that it intends to make these data publicly available in some form by early 2003 (Worboys (CEO, GGAP), pers. comm. May 2002).

The critical issue for the proposed IESC, however, is that to receive base-level certification under GG21, a tourist operation must be judged to rank better than 
the subsector average for environmental performance, even if only marginally better (EAA \& GGAP, 2002). Therefore, fewer than half the tourism operations in any given subsector can receive base-level GG21 certification at any one time, and fewer again can received upper-tier certification. In addition, if GG21 were to become widespread, then theoretically at least, this mechanism should lead to a gradual improvement in the threshold performance required for certification. Technically, therefore, the structures of NEAP and GG21 are incompatible. As long as the combined scheme only certifies a small number of top performers, however, this incompatibility will not become apparent; particularly if each country has different benchmarks, and for most countries there are barely any benchmarking data. In that case, however, the combined IESC is no different from NEAP, which could have gone international quite independently of GG21.

Note that as of mid-2002, NEAP had certified one or more products from each of 242 companies (EAA, 2002). GG21 had 94 certified members worldwide of which 74 are hotels, and individual hotels within a group are counted separately (GG21, 2002). According to GG21, (2002), however, it has 1000 member companies in all. In the Asia-Pacific region these are listed by GGAP (2002).

\section{The Quebec Workshop}

On Sunday 19 May, the day immediately before the World Ecotourism Summit, the Rainforest Alliance and others held a half-day meeting on tourism ecocertification, to present progress reports and consider the STSC proposals. The keynote speakers were Eugenio Yunis of the World Tourism Organisation and Alice Crabtree from Australia's Nature and Ecotourism Accreditation Program. The meeting was also addressed by Martha Honey (IPS), Fergus Maclaren (TIES), Margot Sallows (Greenwich U) and Ronald Sanabria (RA). It was well attended, and the discussion was lively. The Chair of Green Globe 21, Mr Geoffrey Lipman, noted that Green Globe 21 has been viewed as the 'Pac-Man of tourism ecocertification schemes', gobbling up other schemes; and suggested that the proposed Stewardship Council be replaced by a Forum, i.e. a discussion group rather than an accreditation body. Ms Megan Epler-Wood, President of TIES, immediately spoke from the floor in support of his proposal. She noted that this was the first time she had 'agreed publicly with Geoffrey about anything'. The political implications of this are intriguing.

\section{The Future}

The future is far from clear. The political alliances change rapidly. Not long since, NEAP and GG21 were in competition; now they are in cahoots. GG21 seems opposed to an STSC. At the Quebec Workshop, GG21 argued that an STSC would 'just introduce another layer of bureaucracy'. A more likely reason, however, is that GG21 is aiming for global dominance and doesn't want to be subject to accreditation. The Rainforest Alliance and IPS are apparently keen to establish an STSC. The RA, however, is listed as a major supporter of the EAA conference at Cairns where the final IESC is to be released.

There are several practical factors favouring an STSC. (1) It is probably simpler to accredit independent certification systems for different industry subsectors in different countries, than to meld them all into a single scheme. (2) This applies 
particularly to certification schemes which operate in different languages and through entirely different mechanisms, and to award schemes which do not claim to provide formal certification but which are treated as at least their equal. (3) Retail consumers in all industry sectors are rightly suspicious of ecolabels, and indeed other forms of so-called self-regulation, which are operated by private firms or industry associations without oversight from national government agencies or internationally respected environmental groups (Gunningham \& Grabowsky, 1998). In the absence of government standards such as those for recycled and biodegradable products, consumers are more likely to rely on direct endorsement by an established ENGO, a well-known environmental figure, or even an environmentally concerned celebrity, rather than an industry label. Interestingly, FSC has been endorsed by Jennifer Lopez (FSC, 2002).

For many tourism enterprises, the potential value of ecocertification may derive not from retail sales, but from preferential arrangements with environmental regulators such as development control authorities, pollution control agencies, and protected area management agencies (PAMAs). In Australia at least, NEAP certification provides preferential permitting arrangements for tour operators in many national parks, and potential extensions of this approach are currently under very active debate. Whether such regulators will accept industry certification schemes or will opt for those with independent international accreditation remains to be seen. In addition, PAMAs are perhaps more likely than individual tourists to count the number of green ticks on a logo!

From a technical perspective, substantive data on actual environment performance are in short supply. If any performance-based certification scheme successfully signs up enough clients, it will be able to create its own database from these alone. This is unlikely to enhance its credibility, however, unless such data are publicly available and audited.

And finally, should we care? Are ecolabels in tourism worth worrying about one way or another? Unless they lead government to abdicate responsibility to untrustworthy enterprises, or delay the introduction of needed legislation (Gunningham \& Grabowsky, 1998), they probably can't do much harm. Since they are generally far less effective than simple government actions such as building codes or permits to operate in parks, they may not do much good either. They seem to be part of the political landscape at present, but political landscapes are notoriously unstable.

\section{Correspondence}

Any correspondence should be directed to Ralf Buckley, Director International Centre for Ecotourism Research, Griffith University, Parklands Drive, Southport, Qld 4215, Australia (R.Buckley@mailbox.gu.edu.au).

\section{References}

Buckley, R.C. (2001a) Major issues in tourism ecolabelling. In X. Font and R.C. Buckley (eds) Tourism Ecolabelling (pp. 165-174). Oxford: CAB International.

Buckley, R.C. (2001b) Turnover and trends in tourism ecolabel schemes. In X. Font and R.C. Buckley (eds) Tourism Ecolabelling (pp. 189-212). Oxford: CAB International.

CST (2002) Certification for Sustainable Tourism. www.turismo-sostenible.co.cr. Last viewed 13 June 2002. 
CRCST (2002) Cooperative Research Centre for Sustainable Tourism. www.crctourism.com.au. Last viewed 19 June 2002.

Ecotourism Association of Australia (2002) Home page www.ecotourism.org.au. Last viewed 13 June 2002.

Ecotourism Association of Australia and Green Globe Asia Pacific (2002) Setting a Worldwide Standard for Ecotourism: The International Ecotourism Standard for Certification: Draft for Consultation. EAA and CRC Tourism, Australia. www.ecotourism.org.au/ies, www.ggasiapacific.com.au. Last viewed 13 June 2002.

Font, X. and Buckley, R.C. (eds) (2001) Tourism Ecolabelling. Oxford: CAB International.

Font, X., Haas, E., Thorpe, K. and Forsyth, L. (2001) Directory of tourism ecolabels. In X. Font and R.C. Buckley (eds) Tourism Ecolabelling (pp. 271-348). Oxford: CAB International.

Forest Stewardship Council (2002) Home page. www.fscoax.org. Last viewed 19 June 2002.

Green Globe 21 (2002) Sustainable 21st Century Tourism. www.greenglobe21.com. Last viewed 13 June 2002.

Green Globe Asia Pacific (2002) Green Globe 21 Asia Pacific. www.ggasiapacific.com.au. Last viewed 13 June 2002.

Gunningham, N. and Grabowsky, P. (1998) Smart Regulation. Oxford: Clarendon.

Hamele, H. (2001) Ecolabels for tourism in Europe. In X. Font and R.C. Buckley (eds) Tourism Ecolabelling (pp. 175-188). Oxford: CAB International.

Honey, M. (2002) Ecotourism and Certification: Setting Standards in Practice. Covelo, CA: Island Press (in press).

Honey, M. and Rome, A. (2001) Protecting Paradise: Certification Programs for Sustainable Tourism and Ecotourism. Washington DC: Institute for Policy Studies.

The Rainforest Alliance (2002) Conservation Programs: Sustainable Tourism Stewardship Council. www.rainforest-alliance.org/programs/svlgc. Last viewed 13 June 2002.

TUI (2002) Umweltmanagement: Umweltkriterionen für Destinationen. www.tui-umwelt.de. Last viewed 13 June 2002.

Yunis, E. (2002) Keynote presentation to Workshop on Sustainable Tourism Accreditation, convened by the Rainforest Alliance at the World Ecotourism Summit, Quebec. 